\title{
Tingkat Kecernaan Juvenil Ikan Bandeng Chanos-Chanos yang Diberi Pakan Berbahan Tepung Ampas Minyak Biji Kapuk (Ceiba petandra)
}

\author{
Digestibility of Milkfish (Chanos-Chanos) Juvenile Fed With The Diet Contained \\ Kapok Seed Oil By Product Meal (Ceiba petandra)
}

\author{
Ratna Nur Syam¹, Muhaimin Hamzah' ${ }^{1}$, Wellem H. Muskita ${ }^{1 *}$, Agus Kurnia ${ }^{1}$ \\ ${ }^{1}$ Program Studi Budidaya Perairan, Fakultas Perikanan dan Ilmu Kelautan Universitas Halu Oleo \\ Jl. H.E.A Mokodompit Kampus Baru Tridharma, Andonohu, Kendari, Indonesia 93232 \\ *Email korespondensi: wmuskita@gmail.com
}

\begin{abstract}
ABSTRAK
Kendala bahan baku pakan sumber protein nabati tepung kedelai yaitu bergantung impor sehingga disubtitusi menggunakan tepung ampas minyak biji kapuk. Penelitian ini bertujuan untuk mengetahui kecernaan juvenil ikan bandeng (Chanoschanos) yang diberi pakan berbahan tepung ampas minyak biji kapuk. Empat jenis pakan dibuat berdasarkan subtitusi tepung kedelai (TK) dengan tepung ampas minyak biji kapuk (TAMBK) yang terdiri atas :100\% TK; 0\% TAMBK (pakan A), 75\% TK : 25\% TAMBK (pakan B), 50\% TK : 50\% TAMBK (pakan C), dan 25\% TK : 75\% TAMBK (pakan D). Semua pakan percobaan ditambahkan 0,5\% kromium oksida $\left(\mathrm{Cr}_{2} \mathrm{O}_{3}\right)$ sebagai indikator menentukan tingkat kecernaan pada ikan.

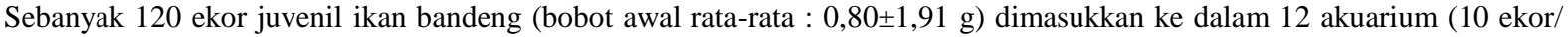
akuarium) yang berukuran $60 \times 40 \times 50 \mathrm{~cm}$. Pemberian pakan dilakukan 2 kali sehari (pukul 08.00 dan 16.00) berdasarkan bobot tubuh selama 60 hari pemeliharaan, kemudian dilakukan pengumpulan feses setiap 3-4 jam setelah ikan diberi makan. Hasil penelitian menunjukkan bahwa perlakuan pemberian pakan berbahan tepung ampas minyak biji kapuk memberikan pengaruh yang sama terhadap tingkat kecernaan protein dan kecernaan total juvenil ikan bandeng (Chanos-chanos). Penelitian ini menyimpulkan bahwa kecernaan protein juvenile ikan bandeng (Chanos-chanos) dalam kategori kurang baik sedangkan kecernaan total menunjukan kisaran optimal.
\end{abstract}

Kata Kunci: Tepung ampas minyak biji kapuk, tepung kedelai, juvenil ikan bandeng Chanos-chanos

\section{ABSTRACT}

The problem with the raw material of vegetable protein source feed soy flour is that it depends on imports so that it is substituted using kapok seed oil pulp flour. This study aims to determine the digestibility of milkfish (Chanos-chanos) juvenile fed with the diet contained kapok seed oil by product meal. Four experimental diets were formulated to contain of based on the substitution of soybean meal (SM) with kapok seed oil by product meal (KSOM) as consisting of: 100\% SM; 0\% KSOM (Diet A), 75\% SM: 25\% KSOM (Diet B), 50\% SM: 50\% KSOM (Diet C), and 25\% SM: 75\% KSOM (Diet D). All experimental diets were added with $0.5 \%$ chromium oxide $\left(\mathrm{Cr}_{2} \mathrm{O}_{3}\right)$ as an indicator to determine the digestibility level in the fish.The organisms used were 120 juvenile milkfish (average initial weight: $0.80 \pm 1.91 \mathrm{~g}$ )were put into 12 aquariums (10 fish / aquarium) measuring $60 \times 40 \times 50 \mathrm{~cm}$. Feeding is carried out 2 times a day (at 08.00 and 16.00) based on body weight for 60 days of rearing, then feces are collected every 3-4 hours after the fish are fed. The results showed that the substitution of soybean flour with the pulp of kapok seed oil had the same effect on the level of protein digestibility and the total digestibility of milkfish juvenile. This study concluded that the protein digestibility of juvenile milkfish (Chanoschanos) was in the poor category while the total digestibility showed the optimal range.

Keywords: Kapok seed oil by product meal, soybean meal, digestibility level, milkfish Chanos-chanos

\section{PENDAHULUAN}

Ikan bandeng dengan nama latin (Chanos-chanos) merupakan salah satu jenis ikan perairan payau bersifat euryhalin atau ikan yang memiliki toleransi yang luas tehadap salinitas yang potensial untuk dibudidayakan, disebabkan permintaan pasar yang cukup tinggi karena harga relatif stabil serta pemeliharaannya yang mudah. Jenis ikan ini sudah dikenal oleh masyarakat luas karena merupakan salah satu sumber protein hewani yang memiliki nilai gizi yang tinggi serta ditunjang rasanya yang enak dan memiliki kandungan kolesterol yang rendah sehingga aman untuk kesehatan. Hal ini sesuai dengan pernyataan Hafiludin, (2015) bahwa ikan bandeng termasuk sumber protein hewani dengan kandungan protein $24,18 \%$ dan lemak $0,85 \%$.

Produksi bandeng secara nasional mengalami peningkatan produksi setiap tahunnya. Akan tetapi pada tahun 2017 hingga 2018 mengalami penurunan yaitu berkisar antara 537.845 ton dan 304.000 ton (KKP, 2018). Menurut Athirah $d k k$. (2013) bahwa 
tingkat produktivitas ikan bandeng dalam budidaya ditentukan oleh faktor laju pertumbuhan, sintasan, kuantitas dan kualitas pakan.

Kegiatan budidaya pakan merupakan nutrisi utama untuk ikan dan memiliki biaya produksi terbesar yaitu berkisar $50-70 \%$ dari biaya produksi Lopes et al. (2017. Tingginya harga pakan dari pabrik disebabkan bahan baku utama pakan ikan seperti tepung kedelai masih didatangkan dari luar negeri sehingga harganya tergolong mahal dan penggunaan tepung kedelai berkopetensi dengan manusia. Oleh karena itu perlu dikembangkan formulasi pakan yang memiliki efisiensi pakan yang tinggi dengan biaya produksi pakan serendah mungkin, tetapi tidak mengurangi kandungan nutrien yang ada pada pakan. Sehingga pencarian sumber protein alternatif untuk menggantikan tepung kedelai yang semakin mahal perlu dilakukan. Selain itu pemanfaatan bahan pakan lokal secara langsung dapat mengurangi biaya produksi pakan ikan.

Sumber utama protein nabati pakan berasal dari tepung kedelai. Tepung kedelai yang digunakan masih mengandalkan produk impor, harganya mahal dan bersaing dengan kebutuhan manusia. Sehingga perlu upaya mencari sumber bahan baku alternatif yang memiliki nilai nutrisi tinggi dan ketersediaannya melimpah. Tepung ampas minyak biji kapuk merupakan produk limbah buangan hasil pembuatan minyak biji kapuk, dimana produk limbah buangan minyak biji kapuk terdiri dari bungkil biji kapuk dan ampas minyak biji kapuk. Herdiana (2019), menjelaskan bahwa ampas biji kapuk memiliki kelebihan yaitu mengandung protein sebesar $23,32 \%$, lemak 5,5\%, dan serat kasar 11,5\% sehingga dapat digunakan sebagai bahan baku pakan. Selain memiliki kelebihan, tepung ampas minyak biji kapuk juga memiliki kekurangan yaitu mengandung zat antinutrisi berupa gosipol dan asam lemak siklopropenat sehingga dalam pembuatan pakan harus dibatasi.

Tepung ampas minyak biji kapuk telah banyak digunakan sebagai bahan baku sumber protein nabati pada pakan ikan. Beberapa penelitian juga telah menggunakan tepung ampas minyak biji kapuk sebagai bahan baku pakan, diantaranya pada nener bandeng (Suriati, 2019); juvenil udang vaname (Nunsir, 2018) yang hasil penelitiannya berkesimpulan bahwa tepung ampas minyak biji kapuk dapat dijadikan sebagai sumber protein nabati sebagai bahan baku pembuatan pakan.

Tepung ampas minyak biji kapuk dapat digunakan sebagai bahan baku alternatif pengganti tepung kedelai. Salah satu evaluasi yang dapat dilakukan untuk mengukur kualitas pakan adalah dengan melihat tingkat kecernaan pakan, untuk itu dilakukan penelitian dengan tujuan untuk mengetahui kecernaan juvenil ikan bandeng (C. chanos) yang diberi pakan berbahan tepung ampas minyak biji kapuk.

\section{BAHAN DAN METODE}

Penelitian ini dilaksanakan pada bulan Agustus sampai Oktober 2020 bertempat di Laboratorium Unit Teknologi Pembenihan dan Produksi, Fakultas Perikanan dan Ilmu Kelautan (FPIK), Universitas Halu Oleo (UHO).

\section{Persiapan Wadah Penelitian}

Persiapan yang dilakukan adalah menyediakan akuarium sebanyak 12 buah berukuran 60x40x50 cm. Akuarium diisi air laut sebanyak $70 \%$ dengan salinitas 15 ppt. Kemudian setiap akuarium dilengkapi dengan selang aerasi. Wadah penelitian ini didesain dengan menggunakan sistem resirkulasi dengan metode Rancangan Acak Lengkap (RAL), terdiri dari 4 perlakuan dan 3 ulangan.

\section{Pakan Uji}

Pakan uji dibuat dengan kandungan kadar protein target 37-38\%. Pakan uji diformulasi dengan mengganti tepung kedelai dengan tepung ampas minyak biji kapuk dan campuran bahan-bahan lainnya pada Tabel 1 . Perlakuan yang diterapkan yakni dosis tepung kedelai dan tepung ampas minyak biji kapuk pada pakan adalah Perlakuan A yaitu $100 \%$ TK dan 0\% TAMBK, perlakuan B yaitu 75\% TK dan 25\% TAMBK, perlakuan C yaitu 50\% TK dan 50\% TAMBK, perlakuan D yaitu $25 \%$ TK dan $75 \%$ TAMBK. 
Media Akuatika : Jurnal Ilmiah Jurusan Budidaya Perairan. 2021. 6(4): 184-191.

Tabel 1. Formulasi Pakan beserta Bahan-Bahan yang Digunakan

\begin{tabular}{|c|c|c|c|c|}
\hline \multirow{2}{*}{\begin{tabular}{|l|} 
Bahan Baku \\
Perlakuan
\end{tabular}} & \multicolumn{4}{|c|}{ Presentase yang digunakan (g/100g) } \\
\hline & $\mathbf{A}$ & B & $\mathbf{C}$ & D \\
\hline Tepung Ikan Peperek & 22 & 22 & 22 & 22 \\
\hline Tepung Kepala Udang & 22 & 22 & 22 & 22 \\
\hline Tepung Kedelai & 25 & 18,75 & 12,5 & 6,25 \\
\hline Tepung Ampas Minyak Biji Kapuk & 0 & 6,25 & 12,5 & 18,75 \\
\hline Tepung Jagung & 10 & 10 & 10 & 10 \\
\hline Tepung Dedak Halus & 10 & 10 & 10 & 10 \\
\hline Tepung Tapioka & 5,5 & 5,5 & 5,5 & 5,5 \\
\hline Tepung Sagu & 3 & 3 & 3 & 3 \\
\hline Minyak Ikan & 0,5 & 0,5 & 0,5 & 0,5 \\
\hline Minyak Jagung & 0,5 & 0,5 & 0,5 & 0,5 \\
\hline $\mathrm{Cr}_{2} \mathrm{O}_{3}$ & 0,5 & 0,5 & 0,5 & 0,5 \\
\hline Minyak Cumi & 0,5 & 0,5 & 0,5 & 0,5 \\
\hline Top Mix* & 0,5 & 0,5 & 0,5 & 0,5 \\
\hline Total & 100 & 100 & 100 & 100 \\
\hline
\end{tabular}

Tabel 2. Hasil Analisis Proksimat Pakan Uji

\begin{tabular}{lcccc}
\hline \multirow{1}{*}{ Parameter } & \multicolumn{3}{c}{ Perlakuan } \\
\cline { 2 - 5 } & A & B & C & D \\
\hline Kadar Abu (\%) & 13,10 & 13,01 & 12,82 & 12,98 \\
Kadar Air (\%) & 1,19 & 1,63 & 1,39 & 1,27 \\
Protein (\%) & 44,80 & 43,44 & 45,65 & 48,04 \\
Kadar Lemak (\%) & 14,71 & 12,99 & 15,37 & 16,25 \\
Serat Kasar (\%) & 7,39 & 4,15 & 7,30 & 5,93 \\
\hline
\end{tabular}

\section{Pemeliharaan Hewan Uji}

Hewan uji yang digunakan dalam penelitian ini adalah juvenil ikan bandeng (C.chanos). Sebelum melakukan penelitian terlebih dahulu ikan uji diadaptasikan selama 1 minggu di dalam bak fiber/media budidaya. Selama proses adaptasi ikan uji diberi pakan komersil. Setelah dilakukan aklimatisasi juvenil ikan bandeng dipuasakan selama 24 jam untuk menghilangkan sisa pakan dalam saluran pencernaannya.

Hewan uji dipelihara selama 60 hari dengan bobot awal rata-rata 1,0-1,30 g dan kepadatan 10 ekor per akuarium. Sebelum pengumpulan feses, hewan uji diadaptasikan dengan pakan uji yang mengandung kromium oksida $\left(\mathrm{Cr}_{2} \mathrm{O}_{3}\right)$ selama 3 hari. Pemberian pakan uji berdasarkan bobot tubuh dengan presentase 5\% dari biomassa juvenil ikan bandeng perhari dengan frekuensi pemberian pakan sebanyak dua kali perhari pada pukul 08.00 dan 16.00 WITA. Selanjutnya dilakukan pengumpulan sampel feses setiap 34 jam setelah pemberian pakan dengan cara disipon.

\section{Variabel yang diamati}

\section{Pengukuran Tingkat Kecernaan}

Kecernaan yang diukur adalah nilai kecernaan protein dan kecernaan total dihitung berdasarkan rumus yang dikemukan Watanabe (1988) adalah sebagai berikut:

Kecernaan nutrien $($ protein $)=100-(100 \mathrm{x}$ a / $\left.\mathrm{a}^{\prime} \mathrm{x} b / \mathrm{b}^{\prime}\right)$

Kecernaan total $=100-\left(100 \mathrm{x}\right.$ a/ $\left.\mathrm{a}^{\prime}\right)$

Dimana: $\mathrm{a}=\% \mathrm{Cr}_{2} \mathrm{O}_{3}$ dalam pakan; $\mathrm{a}^{\prime}=\%$ $\mathrm{Cr}_{2} \mathrm{O}_{3}$ dalam feses; $\mathrm{b}=\%$ Nutrien (Protein) dalam pakan; $b^{\prime}=\%$ Nutrien (Protein) dalam feses

\section{Kromiun Oksida $\left(\mathrm{Cr}_{2} \mathrm{O}_{3}\right)$ dalam Feses}

Kandungan kromium oksida dalam feses diukur menggunakan metode AAS 
Media Akuatika : Jurnal Ilmiah Jurusan Budidaya Perairan. 2021. 6(4): 184-191.

(Atomic Absorption Spectrophotometry) yang dilakukan di Laboratorium Biomolekuler dan Lingkungan Fakultas Matematika dan Ilmu Pengetahuan Alam Universitas Halu Oleo, Kendari.

\section{Protein dalam feses}

Kandungan nutrien (protein) dalam Feses diukur menggunakan metode Kjeldhal (AOAC, 1970) dilaksanakan di Laboratorium Produktivitas dan Lingkungan Perairan FPIKUHO, Kendari.

\section{Kualitas Air}

Selama penelitian berlangsung dilakukan pengamatan dan pengukuran kualitas air meliputi pengamatan suhu air, salinitas, $\mathrm{pH}$, ammoniak dan oksigen terlarut. Suhu dan salinitas diukur tiap hari sedangkan, $\mathrm{pH}$, ammoniak dan oksigen terlarut dilakukan pada akhir penelitian.

\section{Analisis Proksimat}

Pakan uji yang telah dibuat kemudian dianalisis proksimat meliputi kadar abu, kadar air, protein, kadar lemak dan serat kasar (Tabel 2). Analisis kadar abu, kadar air, dan serat kasar menggunakan metode Gravimetri (AOAC, 1970), analisis protein menggunakan metode Kjeldhal (AOAC, 1970), sedangkan analisis kadar lemak menggunakan metode Soxhlet (AOAC, 1970). Analisis proksimat pakan dan kualitas air dilaksanakan di Laboratorium Produktivitas dan Lingkungan Perairan FPIK-UHO, Kendari.

\section{Analisis Data}

Data kecernan protein dan kecernaan total dianalisis menggunakan analisis ragam (ANOVA) dengan taraf kepercayaan 95\% dengan bantuan program SPSS Versi 23,0, sedangkan data kualitas air dianalisis secara deskriptif.

\section{HASIL}

\section{Tingkat Kecernaan Protein}

Hasil perhitungan tingkat kecernaan protein juvenil ikan bandeng (C.chanos) (Gambar 1) tertinggi terdapat pada perlakuan B yaitu $71,24 \%$ dan terendah pada perlakuan C yaitu 63,12\%. Hasil analisis ragam menunjukan bahwa perlakuan pakan uji tidak memberikan pengaruh yang berbeda nyata dimana nilai $\mathrm{P}=0,225>0,05$ terhadap kecernaan protein juvenil ikan bandeng $(C$. chanos) (Gambar 1).

\section{Tingkat Kecernaan Total}

Hasil perhitungan kecernaan total juvenil ikan bandeng (C. chanos) (Gambar 2) tertinggi didapatkan pada perlakuan $\mathrm{D}$ yaitu $92,48 \%$ dan terendah didapatkan pada perlakuan A yaitu 90,49\%. Hasil analisis ragam menunjukan bahwa perlakuan pakan uji tidak memberikan pengaruh yang berbeda nyata dimana nilai $\mathrm{P}=0,198>0,05)$ terhadap kecernaan total juvenil ikan bandeng $(C$. chanos) (Gambar 2).

\section{Kualitas Air}

Hasil pengukuran kualitas air selama penelitian disajikan pada Tabel 3.

Tabel 3. Hasil Pengukuran Kualitas Air selama Pemeliharaan.

\begin{tabular}{lcl}
\hline Parameter & Nilai & \multicolumn{1}{c}{ Optimal } \\
\hline Suhu $\left({ }^{\circ} \mathrm{C}\right)$ & $26-27$ & $\begin{array}{l}26-27^{\circ} \mathrm{C} \\
(\text { Suriati,2019) }\end{array}$ \\
$\begin{array}{l}\text { Salinitas } \\
\text { (ppt) }\end{array}$ & 15 & $\begin{array}{l}10-35(\text { Gufron } \\
\text { \& Kordi,2010) }\end{array}$ \\
pH & 7 & $\begin{array}{l}6,5-9(\text { Raswin, } \\
2003)\end{array}$ \\
DO (mg/L) & 4,9 & $\begin{array}{l}>3(\text { Raswin, } \\
2003)\end{array}$ \\
Amonia & 0,024 & $<0,1($ Raswin, \\
$(\mathrm{mg} / \mathrm{L})$ & & $2003)$ \\
& &
\end{tabular}




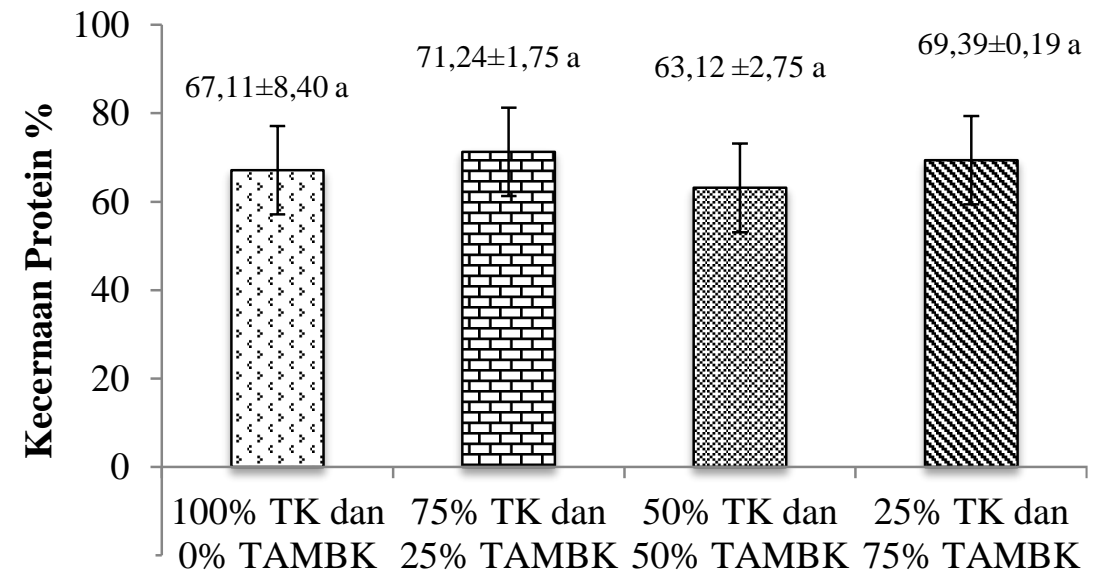

\section{Perlakuan}

Gambar 1. Kecernaan Protein Juvenil Ikan Bandeng (C. chanos) selama Penelitian. Perlakuan A (100\% TK dan $0 \%$ TAMBK); Perlakuan B (75\% TK dan 25\% TAMBK); Perlakuan C (50\% TK dan 50\% TAMBK); Perlakuan D (25\% TK dan $75 \%$ TAMBK). ${ }^{\text {a }}$ superscript yang sama menunjukkan tidak ada perbedaan signifikan pada taraf $\alpha=0,05$.

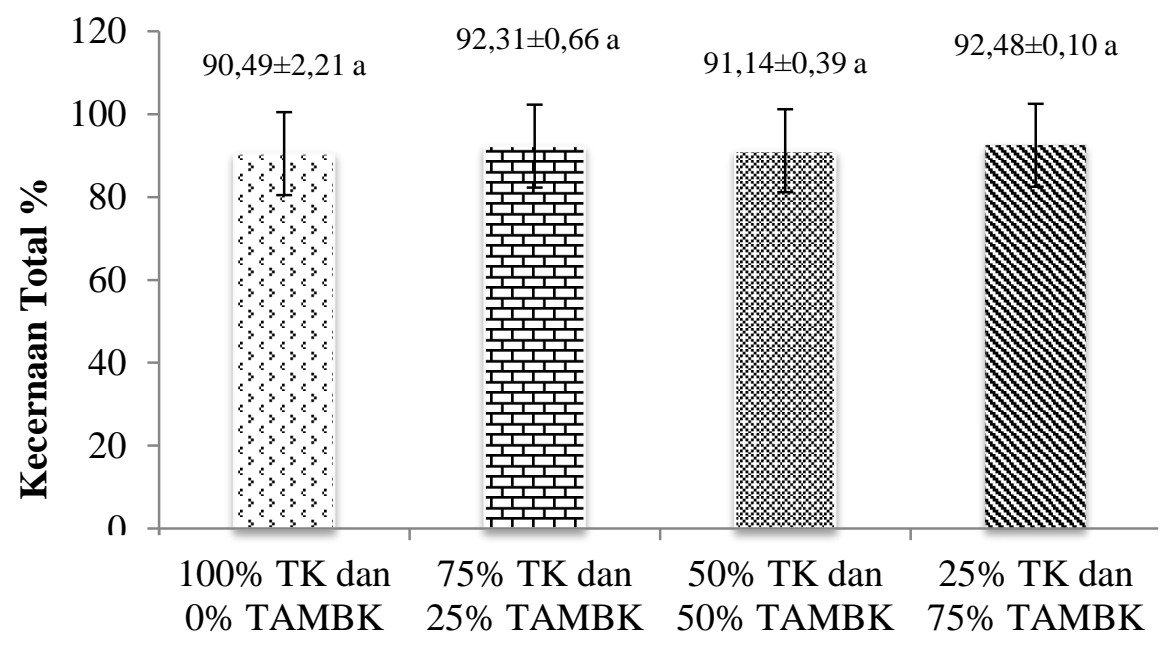

Perlakuan

Gambar 2. Kecernaan Total Juvenil Ikan Bandeng (C. chanos) selama Penelitian. Perlakuan A (100\% TK dan 0\% TAMBK); Perlakuan B (75\% TK dan 25\% TAMBK); Perlakuan C (50\% TK dan 50\% TAMBK); Perlakuan D (25\% TK dan $75 \%$ TAMBK). ${ }^{\text {a }}$ superscript yang sama menunjukkan tidak ada perbedaan signifikan pada taraf $\alpha=0,05$.

\section{PEMBAHASAN}

Kecernaan adalah bagian dari zat pakan yang tidak diekskresikan dalam feses atau dengan kata lain kecernaan didasarkan suatu asumsi bahwa nutrisi yang tidak terdapat didalam feses adalah habis dicerna dan diserap. Kecernaan suatu pakan menggambarkan berapa persen nutrien yang dapat diserap oleh saluran pencernaan tubuh ikan, semakin besar nilai kecernaan suatu pakan maka semakin banyak nutrien pakan yang dapat dimanfaatkan oleh ikan tersebut. Pada penelitian ini didapatkan kecernaan protein ikan bandeng (C. chanos) yaitu berkisar antara 57,42-73,06 \%. Nilai ini masih dalam kategori kurang baik, hal ini sesuai dengan pernyataan NRC (1993); Selpiana 
(2013) yang menjelaskan bahwa kecernaan protein yang baik untuk ikan berkisar antara 75-95 \%. Rendahnya kecernaan protein pada penelitian ini diduga karena kandungan antinutrisi dalam bahan pakan tepung ampas minyak biji kapuk.

Tepung ampas minyak biji kapuk mengandung zat antinutrisi berupa gosipol yang dapat membentuk senyawa kompleks dengan protein dan menghambat kerja enzim proteolitik seperti tripsin dan pepsin (Hasan $d k k$, 2013). Kemudian Masniar $d k k$. (2016), menjelaskan bahwa enzim protease adalah enzim yang berfungsi memecah protein dengan cara menghidrolisa ikatan peptida pada asam-asam amino dalam rantai polipeptida, proses pemecahan makromolekul menjadi molekul lebih kecil sehingga mempermudah pencernaan dan penyerapan di dalam saluran pencernaan ikan, namun karena jumlah dan aktifitas enzim terganggu sehingga proses pencernaan tidak maksimal dan mengakibatkan daya cerna ikan menurun.

Rendahnya kecernaan protein juga diduga karena ukuran ikan yang digunakan lebih kecil, dibandingkan hewan uji yang digunakan dalam penelitian Hamzah et al.(2021), dengan bobot rata-rata 0,85-7,81 g diperoleh kecernaan protein berkisar antara 82,41-86,81\%. Hal ini sesuai dengan pernyataan Saputra (2014), bahwa daya cerna protein dipengaruhi oleh ukuran ikan, semakin besar ukuran ikan maka kecernaan protein semakin tinggi. Hal ini berkaitan dengan system pencernaan ikan dimana ikan yang memiliki ukuran relative kecil tingkat penyerapannya rendah disebabkan enzim pencernaan yang dihasilkan ikan tidak maksimal sedangkan ikan ukuran besar enzim pencernaannya sudah sempurna sehingga proses penyerapan nutrisi pakan akan meningkat.

Kecernaan total pada penelitian ini berkisar antara 87,95-92,91 \%. Nilai ini menunjukan kisaran optimal kecernaan pada ikan. Hal ini sesuai peryataan Abun 2007); Sitta (2014), yang menyatakan bahwa kualitas pakan berdasarkan daya cerna diatas $70 \%$ berkualitas tinggi. Tingginya kecernaan total pada penelitian ini diduga karena kandungan nutrisi dalam pakan sesuai kebutuhan ikan bandeng dan dapat dicerna dengan baik. Hal ini didukung oleh hasil analisa proksimat pakan (serat kasar) yang diperoleh berkisar antara 4,15-7,38 \%. Nilai ini masih dalam kisaran optimal untuk pertumbuhan ikan sesuai dengan pernyataan Rukmana (1997); Iskandar \& Subhan (2017), bahwa nilai kadar serat kasar yang optimal dalam penunjang pertumbuhan ikan yaitu berkisar 4-8\%. Menurut Watanabe (1996); Iskandar \& Subhan (2017), bahwa serat kasar $>10 \%$ akan mengakibatkan daya cerna menurun. Kemudian Anastasia (2020), menyatakan bahwa pertumbuhan nener bandeng $(C$. chanos) dengan pemberian konsentrasi pakan uji yang sama tidak berpengaruh nyata, hal ini disebabkan semua perlakuan memenuhi kebutuhan nutrisi ikan bandeng untuk tumbuh. Fitriliyani \& Indira (2011), menjelaskan pula bahwa kemampuan ikan untuk mencerna bahan baku pakan dipengaruhi oleh faktor kandungan gizi pakan.

Secara umum kualitas air selama penelitian dalam keadaan terkontrol dan sesuai untuk budidaya ikan bandeng. Hasil pengukuran suhu selama 60 hari pada media pemeliharaan berkisar antara $26-27^{\circ} \mathrm{C}$. Kisaran ini layak untuk pemeliharaan dan pertumbuhan ikan bandeng. Hal ini sesuai dengan pendapat Suriati (2019), bahwa suhu normal untuk pertumbuhan nener bandeng berkisar $26-27^{\circ} \mathrm{C}$. Demikian pula pengukuran salinitas yang diperoleh 15 ppt, kisaran nilai ini masih optimal dalam pemeliharaan juvenil ikan bandeng. Menururt Gufron \& Kordi (2010), juvenil ikan bandeng memiliki sifat euryhalin yaitu mampu hidup di perairan dengan kisaran salinitas yang luas yaitu 10-35 ppt.

Hasil pengukuran parameter kimia air berupa $\mathrm{pH}$, DO dan amoniak dalam wadah pemeliharaan selama penelitian yaitu nilai $\mathrm{pH}$ sebesar 7, DO 4,9 mg/L dan amoniak 0,024 mg/L. Pengukuran parameter kimia air menunjukan kondisi kualitas air dalam wadah pemeliharaan dalam kondisi normal, artinya kondisi kualitas air tersebut sesuai dan berada pada kisaran optimal bagi juvenil ikan bandeng dan masih pada kisaran normal serta masih mendukung terjadinya pertumbuhan. Hal ini sesuai dengn pernyataan Raswin (2003), bahwa juvenil ikan bandeng dapat hidup dan tumbuh pada kisaran nilai $\mathrm{pH}$ 6,5-9, konsentrasi oksigen terlarut dalam air >3 $\mathrm{mg} / \mathrm{L}$, dan kadar amoniak tidak boleh lebih dari $0,1 \mathrm{ppm}$. 
Tingkat kecernaan sangat erat kaitannya dengan sistem pencernaan, di dalam system pencernaan terdapat enzim yang berfungsi sebagai katalisator atau pengurai nutrisi menjadi zat yang mudah dicerna oleh ikan. Olehnya itu perlu dilakukan penelitian lanjutan mengenai kinerja enzim pencernaan seperti enzim protease, enzim amilase dan enzim dalam mencerna nutrisi suatu bahan pakan.

\section{KESIMPULAN}

Perlakuan pakan uji berbahan tepung ampas minyak biji kapuk memberikan pengaruh tidak berbeda nyata terhadap tingkat kecernaan protein dan kecernaan total juvenile ikan bandeng (C. chanos).

\section{REFERENSI}

Abun. 2007. Pengukuran Nilai Kecernaan Ransum yang Mengandung Limbah Udang Windu Produk Fermentasi pada Ayam Broiler. Makalah Ilmiah. Fakultas Peternakan Universitas Padjajaran. Bandung.

Anastasia H., Muskita W., Hamzah M. 2020. Substitusi Tepung Kedelai (Glycine max) dengan Tepung Ampas Minyak Biji Kapuk (Ceiba petandra) dalam Pakan Buatan Terhadap Pertumbuhan dan kelangsungan Hidup Nener Bandeng (Chanos-chanos). Media Akuatika 5(4): 156-165. DOI: http://dx.doi.org/10.33772/jma.v5i4.156 15

AOAC (Association of Official Analytical Chemists). (1970). Official Method and Analysis of The Association oh The Official Analytical Chemists. 11th. Edition. Washington D.C

Athirah A., R. Asaf., E. Ratnawati. 2013. Faktor Lingkungan yang Mempengaruhi Produktivitas Menggunakan Aplikasi Analisis Jalur di Tambak Bandeng Kabupten Indramayu Provinsi Jawa Barat. Jurnal Kelautan Nasional. 8(1) :35-47.

DOI: http://dx.doi.org/10.15578/jkn.v8i1.621 9

Fitriliyani \& Indira. 2011. Aktifitas Enzim Saluran Pencernaan Ikan Nila (Oreohromis Niloticus) dengan Pakan Mengandung Tepung Daun Lamtoro (Leucaena Leucophala) Terhidrolisis dan Tanpa Hidrolisis dengan Ekstrak Enzim Cairan Rumen Domba Biocientiae. $8(2): 16-31 . \quad$ DOI: https://doi.org/10.20527/b.v8i2.193

Gufron M. H \& Kordi K. 2010. Nikmat Rasanya-Nikmat Untungnya Pintar Budidaya Ikan di Tambak Secara Intensif. Lily Publisher.Yogyakarta.

Hafiludin. 2015. Analisis Kandungan Gizi pada Ikan Bandeng yang Berasal dari Habitat yang Berbeda. Jurnal Kelautan. 8(1):37-43.

DOI: https://doi.org/10.21107/jk.v8i1.811

Hamzah M., Muskita W.H., Kurnia A., Anshar. 2021. Digestibility of Moringa Leaf Meal (Moringa oleifera) Feed in Milkfish (Chanos-chanos). AACL Bioflux. 14(1):291-297.

Hasan O.D.S., Enang H., M. Agus S \& Eddy S. 2013. Evaluasi Kecernaan Pakan, Kandungan Gossypol dan Asam Siklopropenoat dalam Organ, dan Pertumbuhan Ikan Mas yang diberi Formulasi Pakan dengan Kandungan Tepung Biji Kapuk Berbeda. Jurnal Ris. Akuakultur. $\quad 8(1)$ : 97-107. DOI: http://dx.doi.org/10.15578/jra.8.1.2013. 97-107

Herdiana, R. 2017. Performa Juvenil Udang Vaname (L. vannamei). yang Diberi Pakan Kombinasi Ampas Minyak Biji Kapuk dan Ampas Tahu. Tesis. Universitas Halu Oleo. Kendari.

Iskandar R \& Subhan F. 2017. Analisa Proksimat Pakan Hasil Olahan Pembudidaya Ikan di Kabupaten Banjar Kalimantan Selatan. Fakultas Pertanian Universitas Achmad Yani, Banjarmasin. DOI:

http://dx.doi.org/10.31602/zmip.v42i1.6 44

Kementerian Kelautan dan Perikanan. 2018. Refeksi \& Outlook. Jakarta.

Lopes R.D.S., Eric P.D. A., Mariucha K. H. R. R. 2017. Diet Components as Internal Indicators in the Determination of the Apparent Digestibility Coefficients for Nile tilapia.Universidade Estadual Paulista Júlio de Mesquita Filho (Unesp). Brazil. DOI: https://doi.org/10.1590/S0100204X2017000600003 
Masniar M., Zainal A. M., Sofyatuddin K. 2016. Pengaruh Penambahan Ekstrak Batang Nanas pada Pakan Terhadap Laju Pertumbuhan dan Daya Cerna Protein Pakan Ikan Betok (Anabas Testudineus). Jurnal Ilmiah Mahasiswa Kelautan dan Perikanan Unsyiah. 1(1): 35-45.

NCR. 1993. Nutrient Requirements of Fish. National Academi Press. Washington D.C. USA.

Nunsir N. 2018. Pengaruh Kombinasi Tepung Bungkil Biji Kapuk dan Tepung Ampas Minyak Biji Kapuk (Ceiba Pentandra) terhadap Pertumbuhan dan Kelangsungan Hidup Juvenil Udang Vaname (Litopenaeus Vannamei). Skripsi. Fakultas Perikanan dan Ilmu Kelautan. UHO.

Raswin M. M. 2003. Modul Pengelolaan Air Tambak. Direktorat Jenderal Pendidikan Dasar Dan Menengah Departemen Pendidikan Nasional.

Rukmana, R. 1997. Ikan Mas Budidaya dan Prospek Agribisnis. Kanisius. Yogyakarta.

Saputra D. 2014. Penentuan Daya Cerna Protein In Vitro Ikan Bawal (Colossoma Macropomum) pada Umur Panen Berbeda. ComTech. 5(2): 11271133.

DOI: https://doi.org/10.21512/comtech.v5i2.2 430

Selpiana., Santoso, L., Putri, B. 2013. Kajian Tingkat Kecernaan Pakan Buatan yang Berbasis Tepung Ikan Rucah pada Ikan Nila Merah (Oreochromis niloticus). Jurnal Rekayasa dan Teknologi Budidaya Perairan.1(2) : 101-108.

Sitta F.D. 2014. Pemanfaatan Tepung Keong Mas (Pomacea canaliculata) sebagai Substitusi Tepung Ikan pada Pakan Udang Vannamei (Litopenaeus Vannamei) terhadap Nilai Kecernaan Serat Kasar dan Bahan Ekstrak Tanpa Nitrogen (Betn). Skripsi. Fakultas Perikanan dan Kelautan. Universitas Airlangga. Surabaya. DOI: http://dx.doi.org/10.20473/jafh.v5i1.113 20

Sudrajad A. 2008. Budidaya 23 Komoditas Laut Menguntungkan. Penebar Swadaya. Jakarta.
Suriati., Hamzah M., Muskita W.H. 2019. Pengaruh Pemberian Tepung Ampas Minyak Biji Kapuk (Ceiba petandra) terhadap Pertumbuhan Benih Ikan Bandeng (Chanos chanos). Media Akuatika. $\quad 4(2): 82-92 . \quad$ DOI: http://dx.doi.org/10.33772/jma.v4i2.786 0

Watanabe T. 1998. Fish Nutrition and Mariculture. Departemen of Aquatic Bioscience. Tokyo University of Fisheries. JLCA. 